\title{
AN INVESTIGATION ON A COMPUTER-ASSISTED DIGITAL MUSICAL TEACHING MATERIAL FOR THE SPECIAL EDUCATION OF EDUCABLE MENTALLY RETARDED CHILDREN IN TURKEY ${ }^{1}$
}

\author{
Turan SAĞER \\ Yildiz Technical University, Turkey \\ https://orcid.org/0000-0002-1059-678X \\ tsager@yildiz.edu.tr \\ Günsu YILMA ŞAKALAR \\ Kahramanmaras Sutcu Imam University, Turkey \\ https://orcid.org/0000-0002-6635-5010 \\ gsakalar@,ksu.edu.tr
}

\begin{abstract}
This study investigates the development and application processes of the Computer-Assisted Digital Musical Teaching Material (Co-DiTeachMaterial) designed for easy and enjoyable musical learning of mentally retarded children. Co-DiTeachMaterial-assisted learning for the basic elements of music and recognizing various animated visuals through sounds are important for the development of auditory and visual perception of these children. Experimental study were carried out in special education and rehabilitation center with six children ranging from 7 to 11 . Four modules, are created by researcher, were applied one-to-one to students. Special education teachers were asked to report their opinions. According to both the analysis reports and observation surveys, the children were more successful in the tests of Musical Instruments module than other modules of the material. Results demonstrate that lowest success rate in the Speed module was yielded and a consistent success in the modules of Sound and Environmental Sounds was shown.
\end{abstract}

Anahtar Kelimeler: Educable mentally retarded children, digital teaching material, disability, musical learning, special education and music

\section{TÜRKIYYE'DEKİ EĞİTILEBİLIR ZİHINSEL ENGELLİ ÇOCUKLARIN ÖZEL EĞITIMİ IÇIN BILGISAYAR DESTEKLİ DİJiTAL MÜZIKK ÖĞRETIM MATERYALİ ÜZERINE BİR İNCELEME}

\section{ÖZ}

$\mathrm{Bu}$ araştırma, zihinsel engelli çocukların müziği kolay ve eğlenceli bir şekilde öğrenmeleri için tasarlanan Bilgisayar Destekli Dijital Müzik Öğretim Materyalinin (Co-DiTeachMaterial) oluşturma ve uygulama süreçlerini incelemektedir. Müziğin temel öğelerini Co-DiTeachMaterial destekli öğrenme, bu çocukların sesler ile çeşitli görselleri ilişkilendirebilmesi, işitsel ve görsel algılarını geliştirebilmesi açısından önemlidir. Deneysel bir çalışma olan bu araştırma, Co-DiTeachMaterial'in 7-11 yaş arası özel eğitim ve rehabilitasyona tabi altı çocuk üzerinde yapılmıştır. İçeriğindeki, araştırmacı tarafindan tasarlanmış dört modül, öğrencilere bire bir olarak uygulanmıştır. Ayrıca özel eğitim öğretmenleri görüşlerini bir anket ile belirtmiştir. Analiz raporları ve anket sonuçlarına göre çocukların, materyalin içerisindeki diğer modüllere kıyasla Müzik Aletleri modülünde daha başarılı

\footnotetext{
${ }^{1}$ This research has been supported by Yıldız Technical University Scientific Research Projects Coordination Department. Project Number:2016-08-01-DOP01
} 
olduğu görülmüsşür. Sonuçlar, Hız modülündeki en düşük başarı oranının sağlandığını ve Ses ve Çevresel Sesler modüllerinde tutarlı bir başarının olduğunu göstermiştir.

Keywords: Ĕ̈itilebilir zihinsel engelli çocuklar, dijital öğretim materyali, engellilik, müzikal ögrenme, özel ĕgitim ve müzik

\section{INTRODUCTION: DISABILITY IN THE WORLD AND TURKEY}

Disability causes many restrictions to the human life. Either in the mother's womb or during and after birth or during leading a healthy life that was altered by an unexpected accident, every person is a candidate disabled person. Every disabled individual, regardless of the cause of the disability, should lead a full life, pursue the effort to be a socially active individual and show their abilities, knowledge and skills in every sphere of life.

People's view of the mentally retarded individuals started to change in the 18th century. During this period, they were viewed as good individuals, sorcerers and witches in France; however, later, this view changed to regard mentally retarded individuals as diseased individuals. Before the United Nations defined mental disability, mentally retarded children were regarded as children retarded in their mental faculties and social skills. These children were also known to have difficulties in daily life skills. In 1997, Levenson classified the causes of mental retardation as inheritance, rubella, parental causes, radiation, $\mathrm{Rh}$ factor, blood incompatibility, consanguineous marriage, ages of the parents, emotional condition of the mother, abnormalities during birth premature labor and cretinism (Al-Yaari et al. 2013: 123).

In 1970, the WHO reported that $10 \%$ of the world population comprised disabled individuals; in 2011, this number was reported to be $15 \%$. This number indicates a substantially increasing population. Aside from genetic conditions, this increase may be attributed to the negative changes in the essential needs of human life such as air pollution due to chemical release into air, water and soil, and malnutrition, etc.

Estimations for the prevalence of disabled children in the world population can differ based on the disability type and definition. Accordingly, the Global Burden of Disease (GBD), which is a research program of the WHO, determined that 93 million children had moderate disabilities (5.1\%), whereas 13 million children $(0.7 \%)$ had severe disabilities. In 2005, UNICEF reported that the worldwide population of disabled children over 18 years of age was 150 million (Albrecht et al. 2011: 36).

Since 2002, the Turkish Statistical Institute and the Administration for Disabled People have not conducted any new research on the population of the disabled individuals. The research report from 2002 was announced to the public through the official website of the Institution in 2004. In this largescale research carried out in cities and rural areas of the seven geographical regions of Turkey, disability ratio, socioeconomic structure, the social issues faced by disabled individuals, their expectations, disability type, the cause of disability, regional differences and the presence of any chronic disease were investigated. In the aforementioned research, two surveys that comprise the questionnaire of household and disabled individuals were conducted by face-to-face interview.

According to the 18-months-long research, mentally retarded individuals constituted $0.48 \%$ of the total population in Turkey. The research determined that $47.92 \%$ of the mentally retarded individuals had congenital mental retardation, whereas $49.89 \%$ of the individuals had acquired mental retardation and $2.19 \%$ of the individuals had mental retardation with an uncertain onset date. Of the individuals that live in cities, $49.68 \%$ had congenital mental retardation, $48.29 \%$ had acquired mental retardation and $2.03 \%$ had mental retardation of unknown origin; of the individuals that live in rural areas, $45.99 \%$ had congenital mental retardation, $51.65 \%$ had acquired mental retardation and $2.36 \%$ had mental retardation of unknown origin. Considering the mental retardation prevalence by age, $0.42 \%$ of the children in the $0-9$ age range, $0.58 \%$ of the children and teenagers in the $10-19$ age range, $0.65 \%$

Submit Date: 10.04.2018, Acceptance Date: 11.06.2018, DOI NO: 10.7456/10803100/013 
of the individuals in the $20-29$ age range, $0.54 \%$ of the individuals in the $30-39$ age range, $0.39 \%$ of the individuals in the $40-49$ age range, $0.26 \%$ of the individuals in the $50-59$ age range, $0.27 \%$ of the individuals in the $60-69$ age range and $0.31 \%$ of the individuals aged 70 years or older had some sort of mental retardation. Based upon the results of this analysis, $0.50 \%$ of the children in the $7-11$ age range can be estimated to have mental retardation. The proportion of individuals living in the Marmara Region to the total population was determined as $0.37 \%$. The report did not include information on regional age ranges.

Mentally retarded children exhibit the characteristics of cognitive, physical and psychomotor development as well as social, emotional and language development. The progress of each process varies depending on the individual: While a child with severe mental retardation is trying to develop self-care skills, an EMRChild may have learned the majority of these skills. This is due to the fact that all children have a certain level of learning potential. This potential may also differ in terms of development in the same disability group.

Therefore, a special education program developed by means of one-to-one education and designed for the particular needs of each child should be adopted for each individual child, even for the children in the same disability group. Within the framework of individualized education programs, education methods that support the development of EMRChildren can be applied. Individualized education programs can also be applied in music education. With the development of these programs, they can learn music more effectively.

Technology plays an important role in improving the lives of disabled individuals and utilizing technology in the special education studies can make learning more easy and enjoyable. Since the 20th century, disabled individuals have started to use technology tools and utilize the advantages of technology. At the end of the 19th century and beginning of the 20th century, the USA enacted a law concerning the technology utilization by disabled individuals and integration of technology into special education programs. This law has led to studies on special education technologies and technology application and development in special education. Consequently, in the early 21 st century, technology-supported digital applications directed to the needs of special education was put into the service of disabled students and used in schools and various institutions (Edyburn, 2001: 2-9).

The contribution of computer-assisted music education to special education is paramount. With the advancing technology, various electronic media were developed and these media created opportunities for mentally retarded children to learn music more easily. This enables students to spend a pleasant time with musical activities while attentively participating in classes. This study is of significant importance in prompting the active participation of EMRChildren in musical activities and teaching music through the computer-assisted digital teaching material designed for the music education of them.

\section{Music, Schooling in Special Education}

Education during the childhood period has an important role in the acquisition of cultural and social skills. Both the affective and cognitive advantages of music are more effective in this rapid development period. Children always enjoy listening to music, singing, participating in musical activities and games. Receiving music education, a branch of applied education, in early ages prompt faster learning. This also is true for EMRChildren who only exhibit a slower learning pace and limitations in their ability to store what they learned in their long-term memory.

A musical program that also includes teaching aims to improve the levels of children, offer emotional comfort, allow creative ways to express their opinions, help children acquire relaxation habits and build meaningful social relationships in their daily lives. In line with these purposes, music in special education involves listening, singing, moving in rhythm with music and playing musical instruments.

\footnotetext{
${ }^{2}$ http://www.tuik.gov.tr/PreTablo.do?alt_id=1017
} 
The instruments used in a music program are autoharp, melodic bells, vibrating bells, drums, cymbals and bells, sand blocks, sticks, tambours, tone blocks, triangle and jingle-bracelets, cassette-players, radio, piano and recorders. A special education program should include 15 minutes of music for each day (Tibbetts, 1963: 39-41). Teaching music to EMRChildren is possible through activities such as reciting songs, musical dramatizations, playing games that involve folk dances and songs, exercises to improve the sense of rhythm, listening different music genres, singing popular songs, participating in television and radio shows and listening to radio and gramophone, and physical training such as rhythmic walking, running, jumping, climbing, clapping, pushing, pulling and stretching, and indoor and outdoor games (Showe, 1962: 30-33).

Music studies in special education are known to have a significant effect on children that require special education. Music calms the mental state of children, direct children to a calmer environment and help children overcome aggression, frustration and fear. Experiencing success can help people with mental disabilities fulfil their potential. The goal of these studies, rather than raising individuals who are fully-equipped with musical skills, is to provide a tool that aids their self-expression, their relationship with life and their psychological development. However, the insufficient amount of publications, the lack of material development, inconvenient environment of schools to teach music lessons hinder music education. Moreover, the negative attitude of teachers and school administrators towards music education adds to the main issues faced by music studies in special education (Kinali, 2003: 260; Turan 2006: 25).

In Turkey, the first studies on special education were conducted with hearing-impaired individuals attending to a special education school assisted in 1889 in Istanbul. This school also provided education to visually-impaired individuals. The school had offered a four-year education for students between the ages 6 and 20 and had been active for 30 years and was closed in 1919. A special education school for visually-impaired and hearing-impaired individuals was assisted in İzmir in 1921 and continued its activity under the authorities of the Ministry of Health and the Ministry of Social Security until 1950. In 1951, it was affiliated to the Ministry of National Education. The education of mentally retarded children in Turkey started in the 1952-1953 school year with a total of two special education classes in primary schools in Ankara. Today, attempts to open new schools specialized in this field have increased (Topaloglu 2008: 30). In 1955, the Counseling and Research Center created special education classes for mentally retarded children in schools that offered regular education. They merged under the name of General Directorate of Special Education in 1980 and Special Education Guidance and Counseling Services in 1983. Legal arrangements first started in 1982 with the special education law and continued in 1983 with the law regarding the children that requires special education (Senel, 2006: 255-256).

Researches on computer-assisted teaching in Turkey first started in 1984. In the period between 1985 and 1986, computer laboratories were established in 101 secondary schools. In 1990-1991, 5000 hours of software was created for 141 courses and 5000 teachers were trained in computers and course software. In 1992, the General Directorate of Computer Education and Services (BILGEM) was established within the Ministry of National Education. In 1993, the XIVth National Education Council decided that computer-assisted education should be extended throughout the Turkey, all students should have access to the computers and all lessons should be computer-assisted. Graduate and postgraduate researches in universities and science institutes about computer-assisted teaching include the studies on attitudes towards computer-assisted teaching, researches on preparing course software, model proposing studies, researches to evaluate software, comparative studies between computerassisted teaching and traditional teaching, and other studies (Celikoz, 1997: 479-498).

"The Transformation of Private Education Schools within The Scope of 12-Year Compulsory Education" regulation, established in 2012 by the General Directorate of Private Education Institutions affiliated to the Ministry of National Education, aims to reconstruct private schools that are within the scope of Private Education Institutions Law No. 5580 in coordination with their equivalent state schools. Accordingly, it was decided that private education schools should carry on their activities as 1st stage and 2nd stage schools that comprise of the special education pre-schools, private primary 
schools and private middle schools for visually-impaired, hearing-impaired, orthopedicallyhandicapped and mildly mentally retarded individuals. Moreover, according to this regulation, 1st stage and 2nd stage special education and application centers should carry on their private education activities as 3rd stage schools that comprise vocational training centers and business practice centers. Accordingly, as of 2012, primary schools for mildly mentally retarded individuals that were previously within the scope of primary school program for educable mentally retarded individuals were converted to $1 \mathrm{st}, 2 \mathrm{nd}$, 3rd and 4th grade primary schools for mildly mentally retarded individuals and 5th,6th, 7th and 8th grade secondary schools for mildly mentally retarded individuals. Furthermore, as of 2012, secondary business schools for mildly mentally retarded individuals were converted to 9 th, 10th, 11th and 12th grade 3rd stage special education vocational training centers.

Although music teaching programs prepared for EMRChildren have undergone some changes since 1976, in 1990, with the decision of the Board of Education and Morality dated 9.4.1990 and numbered 44 , they were approved for trial and development and music lessons were determined to be included in the weekly schedule of 1st, 2nd, 3rd, 4th and 5th grades for one period per week (Bezduz, 1996: 65). The investigation on the content of the music lessons that are in accordance with this program reveals that the most prominent feature of the Music Teaching Program for EMRChildren is that it resolved every goal and got the results of these goals as student behavior.

As per the 16th Article, titled "Requirements for primary, secondary and high schools", of the Directive on Standards for Private Education Institutions of the Ministry of National Education dated 2012 and numbered 8108, classrooms for music lessons should have a 1.5-squaremeter area for each student to allow each student to have an area to play musical instruments. Moreover, the article also contains statements that specify the area for technology and design classrooms and painting classrooms in secondary schools as 1.5-squaremeter area per each student and includes these classrooms in the common-area. Furthermore, the "Painting/Music Classrooms" title was included in the Paragraph 13 of the 19th Article, titled "Requirements for Special Education Vocational Training Centers and Special Education Business Practices Centers". This paragraph mandates that weekly class schedules should consider the disability type of individuals (in schools that carry out programs for hearing-impaired, visually- impaired and physically-handicapped individuals or schools for educable mentally retarded individuals) and the area should be at least $15 \mathrm{~m} 2$ (secondary school).

Private Education Institution Regulation of the Ministry of National Education includes Individualized Education Program Development Unit in the boards of the ministry. The relevant legislation states that this unit performs services regarding the preparation, planning and evaluation of the education programs offered in accordance with the primary needs and learning performance of disabled individuals deemed eligible for special education programs by the special education assessment board report.

Along with computer programs developed for disabled individuals, there are various devices and studies that offers ease of life. These studies include three different software-based special education modules comprising of distance education applications for mentally retarded students and distance education applications as well as articular disabilities, autism and mental disabilities for children to enable more easy, cost-effective, short-term and enjoyable education (Ucar, 2007; Aruk, 2008; Topaloglu, 2008; Sakarya, 2011; Yalcinkaya, 2012).

\section{Using Teaching Materials in Special Education}

The inevitability of technology, and especially computer-based technologies, in the processes from the preparation of teaching materials to presentation and evaluation urged educators to seek new theories and application methods. Computerization of teaching materials is one of the reflections of information technology developments in education and the main goal of a teaching material is to enable the target population to reach their full educational potential. Teaching materials, especially by means of computer technologies, provide a basis for this goal and significantly contribute to effective learning. By the nature of disability, disabled students require high levels of personal care. The more the needs of disabled students are met, the more their interest and motivation for learning increase. 
Different teaching materials are required to ensure meaningful learning by promoting their drive for learning and prompting their active participation in learning processes.

Materials are used to support teaching. Well-designed materials enrich the education process, offer concreteness during knowledge assessment and, therefore, make learning easier, reduce forgetting prelearned information, motivate students, intensify student attention, stimulate the eagerness to learn, ensure reaching target behaviors by doing-living, contribute to the conceptualization of ideas and create a more natural learning environment (Ozyurek, 1983; Halis 2002, see also Sen and Senturk, 2014: 173).

At the beginning of the 20th century, pedagogues divided the mentally retarded individuals into three groups; absolute, relative, and apparent. They pointed out that IQ levels of the individuals with mental retardation in the relative group can be improved over time through industrial arts education and making the education more enjoyable. Many pedagogues, psychoneurolinguists, language and speech therapists have stated that the use of visual and auditory items in special education for mentally retarded children is important. These items include candles, whistles, piano, smart devices, mirrors, bubbles, trains, cars and other transport vehicles and simple images containing these items, subjectoriented images that make up a classroom setting or story frames, videos, cassettes, television, slides, videotapes, radio, compact discs (CD), digital videos and computers, and many researches have been conducted on this subject between 1970 and 2011 (Al-Yaari et al. 2013a: 124-125).

Computer-assisted digital teaching materials developed through various software are used in special education as well as they are used in formal education. Concept education is carried out with trainings and materials aimed at improving academic skills. These skills can be taught more effectively and quickly with computer-assisted digital teaching materials. Digital teaching materials used in this area are more effective in special education when supported by concrete materials. Therefore, special education teachers should incorporate all kinds of materials into their teaching methods, whether digital or concrete because the use of material in special education is a necessity in terms of conveying the information in the simplest and clearest way.

A well-designed material allows teachers to use teaching programs more effectively. In the course, it boosts the motivation of the students and encourages active participation. Information transfer is faster and more memorable through material. This also applies to materials used in special education. Given that EMRChildren are slower in transferring information from short memory to long memory, it can be said that the use of the materials related to the subject should be more frequent and repetitive. Therefore, materials are indispensable tools of education and have an importance for students as well as teachers.

Computer-assisted teaching materials play a role in facilitating the learning and understanding of children. In particular, materials (figures, pictures, colors, sounds, music, etc.) supported by auditory and visual items are important means of attracting and intensifying attention for mentally retarded children. Especially in special education, using music as a support for animation in computer-assisted digital teaching materials in music education facilitates learning through the use of multiple sensory organs and helps to intensify the interest on the subject and increases productivity.

The widespread use of the Internet plays an incentive role in the development of new web-based tools and systems in education. In special education, such technologies are very common and various software can be developed. The DataPerfect application is a special education software that evaluates child development through computers. Applications including IEPPro, ClassIEP, netIEP and YagusaSE are used for auditory and visual information technologies in special education. Peker and Arkilic (2013) developed ManSE (Managing Special Education and Rehabilitation Centers), a webbased modular system that may be an additional solution to the existing special education applications. This program allows users to create and develop individual training programs for special education and enables following the progress of students (Peker and Arkilic, 2013: 1091-1093). 
The rapid development of technology has created means to obtain more effective and rapid learning processes in special education and music education. Computer-assisted digital teaching materials created and developed through various software make positive contributions by facilitating both the learning process in the music teaching for EMRChildren and the application of curriculum. In addition, such materials make courses more enjoyable and effective.

\section{Research Model}

The modules in the Co-DiTeachMaterial are configured in four different ways. Each module processes its own musical elements. The modules that process elements of music such as sound, speed, and rhythm contain original sound effects that include the theme of each module. Images created with Photoshop CS4 were transferred to the digital media using a scanner and colored using the same program. Color is an animated and memorable element that describes the drawn characters in the design of visuals. Images in digital media drawn with two-dimensional (2D) computer assisted animation techniques can be applied in multimedia environments in different dimensions. Therefore, the visuals make teaching through visualization and concretization easier and more efficient by means of supporting the visuals with sounds and music that appeal to EMRChildren.

Each module contains visuals from our daily lives. It is to select the visual projected on the screen with the help of sounds. Different from the other modules, Module 3, the Speed module, features short musical pieces that are entitled "Slowly" and "Quickly" and composed by the researcher and structured in an audio recording software. These pieces are projected on the screen in the tempos directly proportional to their names and equivalent to the visual projected on the screen (E.g. Turtle visual: Slow). The goal here is to measure the ability to listen to a slow-tempo piece and relate it to a slowly moving creature. In addition, the names of the pieces were determined in accordance with the observations of the researcher and were used in the title of the pieces to represent repetitive actions. The correct/incorrect state of the given answers or the preferred choices are defined with sound effects. The distinction became clear by representing the correct answer with an applause sound accompanied by green screen, whereas the incorrect answer was represented with a dark sound accompanied by a red screen.

In the material, a program called "the design program" is included so that each module can be reedited. Through this program, teachers can make changes in the modules and save and apply these changes.

The sections that should be in an instructional material that includes goal, acquisition, content and measurement and evaluation, etc. are included in the digital teaching material prepared for the special education music lessons of EMRChildren. Each module has a name, theme, and an achievement. Module names are divided into two sub-titles, each title presents people, animals, musical instruments, environmental sounds, vehicles, weather conditions through sounds and visuals. This section, which consists of 10 samples, constitutes the content of the module. There is a measurement and an evaluation section in each module. A test consisting of ten two-choice questions related to the subject of the module is applied. The modules end with an animation video composed of visuals in the modules so that it highlights the subject. A one-two-minute-long song composed by the researcher was recorded over the visuals that were created with the two-dimensional computer-assisted animation technique to create a video clip to be presented at the end of the modules.

Co-DiTeachMaterial is a computer program that can run on a computer desktop. The technical infrastructure includes the Project.net architecture and the C\# programming language. MSSql was used as the database and special reporting was prepared using Microsoft Reporting. The infrastructure of the program mainly consists of four technical sections; image processing engine, design module, display module and reporting module. The goals of using computer-assisted digital teaching material in special education and music education of EMRChildren in terms of software include allowing the special education teacher to create a special education and music education plan for the education of mentally retarded children by using the visual and auditory items, placing analytical questions in the 
presentation plan both in visual and written form, and evaluating the display plans within the modular structure.

In addition, the goals of the software also include the preparation of tests that can analyze the answers of the students at the end of the modules, the presentation of the prepared modules, multiple application of tests for each module, keeping basic information about the child to whom the module is presented ( $\mathrm{n}=$ infinite) and various analysis of all parameters with the initial parameters. During the designing of the Measurement and Evaluation section of the material, the option "Edit Module Test" was included in the section called "the Design Program". When this option is clicked, the Test Designer window is reflected on the screen. Here, the tests of the modules were prepared in the form of questions and answers for each module and integrated into the material. The section consists of questions, texts, picture-music, correct answers, and incorrect answers, respectively, and allows the preparation of the question type related to the subject in the form of text or picture.

In Module 1 of the material, sound perception (human, animal, musical instruments), visuals and sounds are presented together. Module 2 features Environmental Sounds (humans-animals, vehiclestools and devices, weather conditions), Module 3 features Speed Perception (humans, animals, vehicles) and Module 4 features Musical Instruments (from Turkey and the world) with visuals and sounds.

The Co-DiTeachMaterial in the study was applied with the one-to-one teaching method for the music education of six randomly selected EMRChildren between the ages 7 and 11 who were attending to special education and rehabilitation centers in Istanbul. The software composing the material was prepared by using Microsoft Reporting and the reporting program was collected through statistical data during the application of the digital teaching material through the Research Test created in the software. At the same time, survey questionnaires were presented to the special education teachers who were observers during the application. The results of the tests that were included in the measurement and evaluation sections of the material were analyzed by considering the demographic characteristics of the students. The results of the questionnaire containing the opinions of the special education teachers were also analyzed. Based on the results of the analysis, conclusions and recommendations were presented.

Evaluation of the data were carried out by representing the reporting program included in the software of the digital teaching material with numerical data and interpreting the questionnaire surveys filled out by the special education teachers during the study. All of the modules were conducted in the presence of a music teacher and a special education teacher and in a one-to-one study environment. The music teacher played a role in handling of the modules. When the visual about the subject is clicked, the teacher identified and depicted the visual with the sound. The special education teacher took part in the application as an observer and subsequently reported his/her observations and opinions through the questionnaire.

\section{Data Analysis}

The number of correct and incorrect answers given to the ten-question test in the measurement and evaluation section of the sound perception subject were determined based on the age variable. Accordingly, with a $90 \%$ score, the highest score among the scores of the children aged 7, 8 and 9 was obtained by the 9 -year-old child\%; the 8 -yearl-old child scored $80 \%$ and the 7 -year-old child scored $70 \%$. The average score of the 11 -year-old three children was $66.67 \%$. In general terms, the correct answers of children who participated in the research to the related subject was approximately $68.34 \%$, and, considering that the average success rate was determined as $50 \%$ or above, it can be said that this was a positive tendency.

Examination of the correct and incorrect answers given to the Sound Perception subject in Module 1 based on the gender variable revealed that the male students scored $65 \%$ whereas female students scored $90 \%$. The scores revealed that success rates had varied depending on gender. The seven-yearold and nine-year-old children received equal scores in the Sounds in the Environment subject in 
Module 2. These children gave 9 correct and 1 incorrect answers out of 10 questions. In general terms, it can be considered that the rates of correct answers of children who participated in the research to the related subject was approximately $85 \%$, and, considering that the average success rate was more than $50 \%$, it can be said that this was a positive tendency. Furthermore, considering the $86.67 \%$ score of children aged 11, a higher rate compared to the general success rate $(85 \%)$, suggests that age is directly proportional to the success rate. The three participant children aged 11 supports this finding.

Examination of the correct and incorrect answers given to the Sounds in the Environment subject in Module 2 based on the gender variable revealed that the male students scored $80 \%$ whereas female students scored $95 \%$. Accordingly, it can be said that, compared to the male students, the female students in the experiment group were relatively more successful in the test on the Environmental Sounds subject. The success rate of the 8-year-old educable mentally retarded child in the Speed Perception subject in Module 3 was higher than the success rates of children aged 7 and 9 and the success rate of three children aged 11 . Also, considering that the average success rate was more than $50 \%$, it can be said that this was a positive tendency. There was no significant difference between genders.

Module 4 involved the subject on the Musical Instruments from Turkey and the world, and among the EMRChildren aged 7,8 and 9, with 80, the 8-year-old child received the highest score in the related test. was determined in Since only one correct answer varied, the scores were deemed similar to each other. In addition, the scores of 11-year-old children were also similar to each other. The female students were $100 \%$ successful in recognizing the musical instruments and matching the sound they hear and the related visuals.

Generally speaking, the scores of female students in Module 1 were higher than those of male students. Thus, it can be said that female students are more likely to distinguish the pitch of the sounds of human beings, animals and musical instruments. In Module 2, the scores of female students were higher in terms of recognizing the sounds of humans, animals, nature, vehicles and tools-equipment and matching the sound they hear with the visuals. In Module 3, Perceiving the speed in human, animal and vehicle movements were similar between genders. The similarity between the scores is an indicator of the difficulty of speed perception. In Module 4 called "Musical Instruments", the 100\% success rate of the female students, showed that they picked the visual of the musical instrument they heard more easily and quickly.

In the analysis report based on the age variable, the 7-year-old educable mentally retarded child was more successful in recognizing the environmental sounds compared to the answers given to the other subjects and received the lowest score in speed perception test by answering seven questions correctly. Eight-year-old child correctly answered all the questions in recognizing the musical instruments but received the lowest scores in sounds and environmental sounds with seven correct answers each. The nine-year-old child correctly answered all the questions in recognizing the musical instruments but received the lowest score in speed perception questions. The eleven-year-old children had the highest scores in recognizing musical instruments. The lowest success rate was obtained in the module regarding speed perception. Accordingly, the 8, 9, and 11-year-old EMRChildren were relatively more successful in recognizing musical instruments from Turkey and the world than the 7-year-old child. It is also noteworthy that the number of incorrect answers given to the module regarding the sense of speed by the children aged 7, 9 and 11 years was high.

The general analysis report among the modules showed that $93.33 \%$ of all the students who participated in the research received the highest scores in the definition of musical instruments. The lowest and similar scores were observed in the modules for speed and sound perceptions. Hence, diversifying and repeating the studies to improve the speed and sound perceptions of EMRChildren is important in increasing the success rate.

During the Co-DiTeachMaterial application, a questionnaire was presented to special education teachers. Two female and two male teachers aged between 20 and 40 years who graduated from special education departments of Atatürk University, Anadolu University and Gazi University filled 
out the questionnaire. Two of the teachers had music lessons at the institutions where they had been educated. Three of them were interested in education for mentally retarded children for 6 to 9 years and one of them for 10 to 19 years. Despite the absence of a music room in the special education and rehabilitation center where the research was conducted, some of the teachers have reported that they had music lessons in their educational plans. The materials used by teachers who work on music lessons only consisted of rhythm instruments. The teachers also noted that the digital instructional materials were used in the school for the special education of educable mentally retarded students.

The teachers deemed the digital teaching material, which was designed by the researcher to be used in music lessons in the special education of EMRChildren and applied in the rehabilitation center, beneficial and important in gathering the children's auditory attention and attention in general; they stated that it can be improved and made more complicated through considering the individual development levels; they deemed its computer-assisted structure more effective in drawing the attention of today's children and stated that it helped children to associate sound and shape and contributed to interpreting sounds.

The views of teachers on the positive/negative behavior and attitudes of children during the application of digital teaching material were as follows: The students were able to match rhythm and concepts of music; the students learned the names of musical instruments through the material, albeit not knowing the names of some instruments prior to application; the children gave their full attention during the application of the material and better comprehended the relationship between image and sound; each module should contain different difficulty levels within itself and more subjects should be included in these levels; enabling teachers to reconstruct the material at their own wills was an advantage ; in order for the material to be more functional, it should contain a controllable panel or a moveable button for students.

The views of teachers on material development were as follows: The material should be used in other studies on different age groups and disability types; the subjects included in the material should be gradual so as to contain beginner, intermediate and advanced levels; the fact that it enabled teachers to improve the material was noteworthy; the material could and should be applied to children with hearing impairment, attention deficiency and hyperactivity disorders.

\section{RESULTS AND DISCUSSION}

In the data obtained from the researches in the developing countries, as well as those in the developed countries, the inadequacy of education and the lack of working opportunities are seen as disadvantages for the retarded people. According to these studies, the lower employment rates and education levels among disabled individuals, also adds to these disadvantages. The same applies to children with disabilities. Whatever the calendar ages of EMRChildren are, their intelligence scores vary to some extent. Therefore, memory and perception skills of these children are weaker than their peers. From this point of view, it is extremely important to carry out special education music lessons for EMRChildren in an individualized educational environment. A digital music teaching material, which can be used in music lessons made in an individualized educational environment, enables the lessons to be more efficient and plays a role in increasing the student's attention.

By using Co-DiTeachMaterial in special education music lessons, lessons that contain an individual training-based animation and games should also be included in the music curriculum. Thus, it will help the consolidation of the subject. An individualized educational program should also be included in music lessons. Visually-supported musical activities are beneficial in facilitating music education. More frequent, longer-term systematic studies of such researches will significantly contribute to the education of EMRChildren aimed to improve their auditory perceptions through visual items.

The research showed that the correct answers given without hesitation has an important place in the development of self-confidence of the EMRChildren. The fact that these children are not insensitive to the environment and they are able to relate musical instruments to the visuals without hesitation is a 
sign that they can recognize these instruments. From this point of view, teaching various musical instruments to EMRChildren with visual support also contributes to the motor skills, imitation skills, social skills and expressive language skills included in the recommended special education services. Studies conducted through various musical activities and methods are important in order to activate the auditory perception stimulation of EMRChildren through music. Recognizing a musical instrument through visuals and perceiving it through visuals and music, accelerates this process.

Such studies improve the matching skills of them. Such materials can be enriched with various matching games and make learning more enjoyable and permanent. Thus, motivation is increased and positive contributions are made to eliminate attention deficit. Sensitivity to the environment is vital to them as it is to every child. The ability to associate and recognize everything in our surroundings with sounds has a more effective role in memory and makes it easier to recognize. Therefore, the approach to what is recognized is even more different. Thus, EMRChildren can be more sensitive to their surroundings, able to recognize their environment, and they can develop social adaptation skills with such studies.

A study conducted in the digital medium can facilitate the education of EMRChildren. The results of the research showed that modules designed as a digital teaching material for special education teachers can be easily used in the music education in special education. The different success levels of EMRChildren of different genders and ages, indicates that physical, biological and cognitive success of these children may be related to the success rate. Regarding this situation, it is essential that various scientific researchers are made and various proposals are produced based on the findings. This material is a pioneer for developing and writing more advanced programs for children who have completed the first stage of education. In this direction, new programs should be written and implemented according to different levels of education.

The lower scores obtained by the EMRChildren in the speed perception compared to the other topics in digital teaching material necessitates further research on this subject. Because knowing, learning and understanding that an object, a vehicle or a living thing moves fast or slowly provides serious benefits for these children to facilitate their daily lives.

In order to increase the level of education in music education in special education in Turkey and the world, specialized music teachers should work in special education and rehabilitation centers. Each institution should have a music room and music education courses should be taught with individualized music education. Curriculums should be created for music courses regarding this field and music books should be written. Music lessons must be supported with a material. A scholar researcher group should be formed who have studied disability at the undergraduate and graduate levels and have adopted a critical approach to the subject. For special education, individuals with strong interdisciplinary skills should be trained in a range of disciplinary fields such as music, art, sociology, philosophy, musicology, music education and psychology. In this manner, a connection should be established between the universities in the developed countries and the universities in the developing countries.

\section{REFERENCES}

Albrecht, Gary, (2011). Disability - a Global Picture. Chap. 2 World Report on Disability, edited by Sally Hartley, Venus Ilagan, eds., 36. Malta:World Health Organisation Pub.

Al-Yaari, Sadeq and Ali Saad, Fayza Saleh Al Hammadi, Salah Ayied Alyami, (2013). Teaching Mentally Handicapped Children (MHC) Using Audio-Visual Aids: A Pedagogic \& Psychoneurolinguistic Approach. International Journal of Language Education, Vol. 1, No:2, Special Issue, ISSN: 2325-0887.

Aruk, Ibrahim, (2008). The Usage Of Informatic Technologies For Mentally Disabled in E-Learning and The Improvement Of An Application As An Example. MComp diss., Trakya University. 
Bezduz, Karatas, Reyhan, (1996). Examination and Evaluation of the Primary School Music Lesson Training Programme Educatible 'Mentally Disabled' Children. MEd diss., Gazi University.

Celikoz, Nadir, (1997). Türkiye'de Bilgisayar Destekli Öğretimle İlgili Yapılan Çalışmalar. [Studies on Computer Assisted Instruction in Turkey]. Eğitim Yönetimi, Yll 3, Sayl 4, 479-498.

Edyburn, Dave L. (2001). Critical Issues in Special Education Technology Research: What Do We Know? What Do We Need to Know?. Advances in Learning and Behavioral Disabilities, edited by M.Mastropieri \& T. Scruggs (eds.), 95-118., NY: JAI Press.

Kinali, Gulsevim. (2003). Zihin Engellilerde Beden-Resim-Müzik Eğitimi. Farklı Gelişen Çocuklar, Edited by Adnan Kulaksizoglu, 260. Istanbul: Epsilon Press.

Milli Egitim Bakanlıgl, Ozel Ogretim Kurumlari Genel Mudurlugu, "Ozel Ogretim Kurumlari Standartlar Yonelgesi", 8108, (Agustos 2012): 6-8.

Milli Egitim Bakanlıgl, Ozel Ogretim Kurumlari Yonetmeligi, MEB Mevzuat, Resmi Gazete, 28656, Mayis 2013

Milli Egitim Bakanligl, Ozel Ogretim Kurumlari Genel Mudurlugu, "Ozel Egitim Okullarinin 12 Yillik Zorunlu Egitim Kapsaminda Donusumleri”, Yonetmelik, 143107, (Kasim 2012): 1-6

Sakarya, Ali, (2011). Development of Distant Learning System for Mentally Disabled Children in the Moodle Environment. MComp diss., Trakya University.

Showe, Janet, (1962) A Guide For Teaching Educable Mentally Retarded Children in Primary and Intermediate Levels in Special Classes in New Haven, Connecticut. MSci diss., Southern Connecticut State College.

Sen, Sevim, Ulku and Nezihe Senturk, (2014). Software Model (Based on the Methods of Programmed Instruction) Developed to be Used in Elementary Music Education, Journal of Education and Social Science, Number 202: 170-191.

Senel, Gunayer, Hatice, (2006). Special Education in Turkey. European Journal of Special Needs Education 13:3, 254-261. doi: 10.1080/0885625980130304.

Tibbetts, Donald, Gene, (1963). A Curriculum For Educable Mentally Retarded Children. MA diss., The Graduate Faculty of Chapman College.

Topaloglu, Murat, (2008). Distance Education of Handicapped Children and Developing a WebBased Software System. MComp diss., Trakya University.

Turan, Duygu, (2006). A study on the Teachers' Point of View About Problems Encountered During Utilisation of Music for Special Education. MEd diss., Marmara University.

Turkiye Istatistik Kurumu Analizleri [Turkish Statistical Institute Analysis], (2004). Engelli İstatistikleri [Disability Analysis] Accessed September 15016. http://www.tuik.gov.tr/PreTablo.do?alt_id $=1017$ 